\title{
Energy Security and NATO: Any Role for the Alliance?
}

\section{Zurab Khamashuridze *}

\section{Introduction}

This paper is meant to address issues related to energy security in the twenty-first century, and to identify areas where NATO could add value to the world's overall energy security environment, and in particular how it can improve the security of critical energy infrastructures. Increased demand on energy resources, driven mainly by economic growth and demographic developments in Asian countries, particularly China and India, has removed spare capacity from the energy market, which has translated into price hikes for energy resources, thus causing immense economic damage to nations that are heavily dependent on energy imports.

Energy scarcity and the inability of energy producing countries to increase exploration and extraction capacities creates additional tensions on the energy market and even causes friction between states in their efforts to secure energy resources. Aging energy infrastructures in some producer countries, combined with political instability and the increasing tendency of energy producing states to use their export potential for political leverage are additional sources of concern for European consumers.

Terrorist organizations have recognized the vulnerabilities of Western economies, and have adopted the policy of "petroterrorism," which aims to cause interruptions in energy flow and inflict economic damage on the United States and other Western nations. Threats of terrorist attacks on the energy infrastructure have become an issue of increased attention and discussion in Western societies and institutions, such as the European Union and NATO.

Concerns about energy insecurity have prompted NATO to raise the issues for discussion within the Alliance. As early as the organization's Strategic Concept of 1991, and then later in 1999, Allied nations recognized the disruption of the flow of vital natural resources as a potential threat and challenge to the organization in the coming century.

Though energy security and the security of critical energy infrastructure elements are not new topics for NATO, the Alliance has still not defined a clear role it might play in securing energy flows to its member states. However, there are certainly areas where the Alliance could add value. By patrolling the world's strategic energy chokepoints, conducting monitoring and threat assessments on maritime shipping lanes, and providing training and support to domestic security services, NATO could play a significant role in securing the flow of the world's energy resources. Protecting critical energy infrastructure, providing Allied solidarity in cases of the disruption of energy flows to one of the Allied nations, and even carrying out interdiction operations are the issues NATO has to address in the immediate future.

Mr. Khamashuridze is Head of the Department for Relations with International Organizations in the Office of the State Minister for Reintegration in Tbilisi, Georgia. 


\section{Energy Security in the Twenty-first Century}

The failure to agree on a new price formula for Russian gas shipped to Ukraine, and the resulting cutoff of the nation's gas supply by the Russian gas monopoly Gazprom on 1 January 2006, prompted many European experts and government representatives to think about the reliability of their own countries' energy supply. Some experts talked about a "gas crisis," and even raised the specter of a new "Cold War" era.

While the legitimacy of demanding higher prices for energy is virtually impossible to contest, what made the experts so worried were political motivations for the prices increases, and the inability to resolve such disputes in the absence of viable regulatory mechanisms. Another issue these problems raised (and not for the first time) was that of single-supplier dependence in an era of rising energy nationalism. Whereas the 1 January events were hyped as the turning point in Europe's perception of its energy vulnerability, many experts failed to react to the increasingly assertive energy politics of the Russian Federation vis-à-vis its neighbors. The explosion of two main gas lines supplying Georgia with Russian gas was not met with an adequate reaction from the West.

Increasing demand for energy resources, especially in countries such as China and India, and rising prices for gas and oil have put energy supply and energy security issues once again at the top of the world's energy agenda. Recent developments showed that energy issues are assuming increasing geostrategic importance, and have become an integral part of the foreign policy of some producer countries.

European fears of energy insecurity have been made more acute by the aggressive politics of the renationalization of energy resources in producing countries such as the Russian Federation, Venezuela, and Saudi Arabia, as well as by the anxieties caused by Iran's nuclear ambitions and its threats to block the flow of natural resources through the Straits of Hormuz. Debates about setting up a "Gas OPEC" and shifting deliveries from the European market to Asian consumers further increased European fears.

What is energy security? This is one of the most frequently asked questions of the last few years. Is it the uninterrupted flow of energy from one point to another? Or is it a diversified array of energy supplies, thus securing the flow if one source fails? For the purposes of this essay, energy security is taken to mean reliable access to energy in sufficient volume at affordable prices under the framework of a viable regulatory regime. This concept of energy security has also been recognized by the European Union, which set up a comprehensive system for settling disputes on matters covered by the Energy Charter Treaty. The Russian-Ukrainian gas dispute of January 2006 once again highlighted the need for a regulatory mechanism. Protection of energy infrastructure is also an integral part of energy security.

When considering energy security, one of the primary questions to be answered is whether there are enough resources to cover the growing world demand for energy. European concerns about energy security are linked to developments on the Russian energy market, the exploration and development (upstream) capacities of Central Asian 
producing countries, and of course to the investment climate in energy infrastructure in Russia and the littoral states of the Caspian Sea. ${ }^{1}$

Recent estimates by the International Energy Agency provide a rather pessimistic picture of the world energy market. Total world consumption of energy is projected to increase by 57 percent by $2030 .^{2}$ European demand for energy resources will increase for the next twenty-five years. Gas consumption in particular is projected to increase from the current 520 billion cubic meters (bcm) a year to approximately $800 \mathrm{bcm}$ in $2030 .^{3}$ Oil consumption will also rise dramatically, from the current rate of 16 million barrels per day (mbd) to $20 \mathrm{mbd}$ in 2030. Gas consumption by European Union members will increase from the current level of 57 percent of the EU's total energy consumption to 80 percent in 2030. The Russian share of Europe's gas consumption is currently about 30 percent, and is projected to increase to 60 percent by 2030 . Today Russian gas accounts for 70 percent of European gas imports (the rest comes from Algeria).

Europe's increasing dependence on Russian energy and the Kremlin's strategy of monopolization of the energy market-with Gazprom at the forefront ${ }^{4}$ - is an issue of security concern in most European capitals and institutions. Concerns about dependence on a single supplier are being further aggravated by proposals to create a "Gas OPEC" — an idea floated by President Ahmadinejad of Iran, another energy-rich country, which was picked up by President Putin of Russia. The creation of a gas cartel, which would also include Central Asian producer countries such as Kazakhstan, Turkmenistan, Uzbekistan, and other major energy producers like Algeria and Iran, would expose net importer (consumer) countries to the potential of energy being wielded as a weapon for political purposes. Though many experts since then have questioned the rationale behind the idea of setting up a "Gas Cartel," pointing to the divergent political agendas of the possible members, several developments indicate the logic behind the prospect.

First, if a Gas Cartel were created, the dominant role would fall to Russia as the richest nation in terms of gas reserves. Russia is also the biggest gas producer and exporter in the world, which would effectively make Russia the "new Saudi Arabia of gas." Second, having a preferred position, the Russian gas sector would guarantee itself the greatest benefits by preventing projects that might compete with its own

1 Andreas Goldthau and Oliver Geden, "Europas Energieversorgungssicherheit—Ein Plädoyer für einen pragmatischen Ansatz,” IPG 4 (2007).

2 International Energy Agency, International Energy Outlook 2007, available at www.eia.doe.gov/oiaf/ieo/.

3 Ibid.

4 Enno Harks, "The Conundrum of Energy Security: Gas in Eastern and Western Europe,” The International Spectator 41:3 (2006).

5 Vladimir Socor, “Gas Supplier's Cartel: Not an 'OPEC,' but a Cartel all the Same,” Eurasia Daily Monitor 4:62 (29 March 2007); available at http://jamestown.org/edm/article.php? volume_id=420\&issue_id=4052\&article_id=2372055. 
agenda. ${ }^{6}$ This is important especially when looking at recent instances where Russia has used political and economic leverage to conclude energy deals with Central Asian countries under preferred conditions, thus positioning itself as a virtual monopolist in bringing Central Asian gas and oil to the European markets.

Russian energy policy is not the only issue of concern for European consumers. They are also concerned about underinvestment in the energy infrastructure in Russia. Stagnation in the upstream sector raises many questions as well. Steadily increasing Russian domestic gas demand, which accounts for 67 percent of Russia's entire production, is also an important factor to be taken into account. Russia's annual increase in demand of 4-6 percent is mostly driven by the need to produce more electricity to support the growing economy. ${ }^{7}$

It is worth mentioning that Russian gas production has currently peaked; in fact, production in the three giant gas fields at Yamburg, Urengoy, and Medvezhye is decreasing. In the newly developed fields, gas production has already reached its maximum as well. In order to offset the gap between gas production and gas consumption, new gas fields have to be developed. Such developments are very important for meeting contractual commitments to European consumers. However, the vast majority of new gas fields are located in areas with severe arctic conditions that are very difficult to access. There are overwhelming technical challenges that are likely to translate into high exploration and production costs. According to the OCDE assessments, there is a need to invest more than USD 25 billion in exploration and production for the Yamal Peninsula and Ob-Taz Region. In addition, USD 40 billion is needed to invest in the construction of pipeline systems. ${ }^{8}$

According to a survey conducted by the United Bank of Switzerland, in order to fulfill all export commitments through 2010 and cover domestic demand-to which Gazprom is legally bound-there is a need to achieve a total projected production of $560 \mathrm{bcm}$. Additionally, the whole of Central Asia's export capacity and contribution from the independent Russian producers is necessary to meet this need. ${ }^{9}$ Restrictions on the participation of independent foreign investors in exploration and production processes makes foreign companies and a few Russian independent producers reluctant to increase their extraction capacities, which poses a serious risk to energy security.

Many experts believe that issues related to energy supply and energy security are of an economic nature, and that only the markets can dictate the policies that will need to be adopted in this arena. However, it is highly unlikely that markets alone will be able to ensure the necessary level of energy security. ${ }^{10}$ According to Susanne Peters, of

6 Matteo Fachinotti, “Will Russia Create a Gas Cartel?” Russian Analytical Digest 18 (Zürich: Centre for Security Studies, ETH Zürich), 3 April 2007.

7 Daniel Simmons and Isabel Murray, “Russian Gas: Will There Be Enough Investment?” Daily Estimate (25 September 2007); available at www.dailyestimate.com/article.asp?id=11200. Ibid.

10 Dr. Ariel Cohen, “Target: Energy, IAGS Energy Security,” available at http://www.iags.org/ n111104c.htm. 
Kent State University’s Geneva Semester Faculty, liberalized energy markets and selfregulatory policies alone cannot provide energy security by simply dictating when and to what extent to increase energy production. Peters writes:

Firstly, world energy markets are not liberalized. Rather, there is a trend toward energyrenationalization. Western oil companies only have full access to 6 percent of the world's known reserves. They can invest in an additional 11 percent of reserves through joint ventures and production sharing arrangements. But the rest of the world is closed to them. Currently 72 percent of the world's oil reserves are held by national oil companies. That is no global liberalized market. ${ }^{11}$

The latest trends show that Russian, Chinese, and other foreign, mostly state-owned/ controlled energy companies do not really focus on achieving commercial profits and being cost-efficient, but are rather conducting their energy policy based on security and foreign policy considerations. Russian Foreign Minister Sergey Lavrov, in an article submitted to the journal Foreign Affairs but later withdrawn, stated that: "Russia does consider energy to be a strategic sector that helps safeguard independence in its foreign relations. ... The Russian government's energy policy reflects a global trend toward state control over natural resources." ${ }^{12}$

The fact that Soviet-era pipeline systems are mostly outdated and generally in poor condition amplifies concerns about the reliability of energy deliveries to European consumers. Frequent leaks not only affect energy prices, but also pose a serious threat to the environment. In 2006, the Russian General Accounting Office estimated that 57 percent of the pipelines in Russia are already worn out. Furthermore, Russian security arrangements do not provide sufficient protection for thousands of kilometers of pipelines, not to mention hundreds of refineries and oil/gas terminals. ${ }^{13}$

Since Europe is already the second-largest energy consumer and importer of natural resources after the United States, it also relies to a great extent on the stability of world energy markets. The Middle East and Persian Gulf regions play a very important role in Europe's energy security and diversification policy. The global war on terrorism, military operations in Afghanistan and Iraq, and instability in Africa will also play a significant, if not decisive role in shaping European energy policy. Moreover, there is significant potential for future conflicts in the Middle East and Persian Gulf region, which could lead to shortages and interruptions of energy supplies to European and

11 Susanne Peters, “The Future Energy Security Environment: No Alternative to a Radical Shift,” Kent State University, Geneva. Published in Energy Security and Security Policy: NATO and the Role of International Security Actors in Achieving Energy Security, ed. Phillip Cornell (Oberammergau: NATO School, November 2007).

12 Sergey Lavrov, Foreign Minister of the Russian Federation, "Containing Russia: Back to the Future?”; available at www.globalresearch.ca/index.php?context=va\&aid=6373.

13 Adrian Kendry, "NATO and Energy Security,” in Energy Security and Security Policy: NATO and the Role of International Security Actors in Achieving Energy Security, ed. Phillip Cornell (Oberammergau: NATO School, November 2007); available at www.isn.ethz.ch/ pubs/ph/details.cfm?v21=106904\&lng=en\&ord61=alphaNavi\&ord60=PublicationDate\&id= 56272 . 
Western markets. Any interruption of energy flow would translate into increased energy prices, with dramatic consequences for national, regional, and transnational economies, especially in the era of globalization.

Only six states of the Gulf Cooperation Council control 45 percent of proven oil reserves and 15 percent of proven global gas reserves. Adding Iran and Iraq to this mix, this group's holdings account for respectively 65 percent and 35 percent of world oil and gas reserves. Based on these figures, one could easily understand the importance of the region for global energy security. OPEC's reluctance to increase oil production could also challenge the world's energy security in the future. Unlike the oil crisis of 1973, when OPEC could enforce a price rise increase for the short term, today it would be quite easy for OPEC to change the power balance in favor of producer countries. It is foreseen that in 2020 OPEC will cover more than 50 percent of Europe's oil consumption, and this number will increase as the rate of oil extraction and production in the North Sea declines. A critical look at oil reserves of Saudi Arabia gives one pause, especially in view of the fact that for the last couple of years the government of Saudi Arabia has rejected all proposals to conduct verification of its proven strategic reserves. ${ }^{14}$ Some experts believe that the oil reserves in Saudi Arabia are significantly lower than officially represented.

Not only do the assertively nationalistic energy policies of producing countries, declining energy production, and poor infrastructure conditions threaten world energy security, but terrorist attacks on pipelines and refineries also pose a very serious challenge to the uninterrupted flow of energy. Gal Luft, writing in the Washington Post, raised the specter of an "energy Pearl Harbor" that could have had devastating effects on the world's economy if the terrorist attack on Saudi Arabia's Abqaiq oil terminal had succeeded. In his words, today's energy market looks like a car without shock absorbers: "the tiniest bump on the road could send consumers and prices bouncing off the ceiling." 15 Unlike the early 2000s, when some oil producers (mainly Saudi Arabia) could produce spare capacity, thus bringing the energy market into equilibrium, today it is virtually impossible to produce enough spare oil to stabilize the energy market. Increasing demand for energy recourses in the world and a near-desperate quest for any additional oil took spare capacity off the upstream sector. Whereas in the early 2000s there were about 7 mbd (10 percent of annual world consumption) of spare capacity, today it is unlikely that oil producing countries could absorb shocks caused by terrorist attacks or natural disasters. Any attack on energy infrastructure could cause price hikes in oil and gas and leave hundreds of thousands of people jobless. As Neal Adams put it at the Energy Symposium organized by the Institute for the Analysis of Global Security and Foundation for the Defense of Democracies, "Oil is an effective weapon. The weapon is a sudden disruption in oil supply. This immediately translates into a shock of the global energy economy." 16 The attempted attack on the world's biggest oil refin-

14 André Salem, “Wundersame Ölvermehrung,” Internazionale Politik 62:2 (February 2006).

15 Gal Luft, “An Energy Pearl Harbor?” The Washington Post (5 March 2006).

16 Institute for the Analysis of Global Security, “Target: Energy, IAGS Energy Security”; available at www.iags.org/n111104c.htm. 
ery Abqaiq was not the only terrorist act aimed at collapsing the world's energy supply. In 2002 Saudi security services arrested a group of terrorists targeting the world's largest offshore oil facility, Ras Tanura.

The potentially devastating effects caused by the possible interruption of energy flows therefore put energy infrastructure in the crosshairs of terrorist organizations such as Al Qaeda. According to information provided by the European Commission's Global Monitoring for Environment and Security Program (GMES), in recent years terrorist attacks on energy infrastructure, particularly oil stations, have increased significantly and have taken on a global character. Attempts by terrorist groups to interrupt the flow of energy resources have taken place in Algeria, Columbia, Ecuador, the Philippines, Russia, Pakistan, Iraq, and Turkey. In the period from 2003 to 2006, more than 300 incidents and attacks were registered. The numbers demonstrated by the GMES, however, do not provide a complete picture of the problem.

Terrorist organizations have put "energy jihad" at the top of their political agenda. They pursue a policy of bleeding Western countries and the United States to bankruptcy by targeting critical energy infrastructure. ${ }^{17}$ Furthermore, their tactics and methods aim at having broad media coverage when explosions and trails of flames on oil fields are immediately broadcast, thus causing panic on the energy markets.

Al Qaeda has adopted a policy of "petroterrorism" aimed at causing interruptions in energy flows and inflicting economic damage on the West. Iraq, for example, is used as a training ground for terrorists in attacking energy infrastructure. Taking Iraq as an example, one can calculate that attacks against energy infrastructure carried out by terrorists remove approximately one million barrels per day from the global energy supply. Many experts claim that if this capacity were in the energy market, it would have had a direct impact on oil prices reducing it by USD 10 to 15 per barrel.

A "Map of Future Al-Qaeda Operations" posted on the Internet on 12 February 2005 listed the organization's priorities. Among others was listed: "targeting the American points of interest in all the countries, mainly oil facilities in the Persian Gulf that represent the main artery of the American economy. Cause harm to the American economy as a result of the rise in the price of oil, cause an embarrassment to America before all the countries in the world, which will be certain of America's inability to provide oil supply contrary to what it claims....”18

Nigeria, the country with the largest oil and gas reserves in Africa, is yet another unstable region Western consumers are dependent on. The country supplies 19 percent of European crude oil consumption, and 42 percent of the country's crude oil exports are shipped to the U.S. In the Niger Delta region, local armed groups competing for a bigger share of oil revenues are fighting against each other using subversive tactics and

17 Pavel K. Baev, "Reevaluating the Risks of Terrorist Attacks Against Energy Infrastructure in Eurasia,” China and Eurasia Forum Quarterly 4:2 (2006); published by the Central AsiaCaucasus Institute Silk Road Studies Program, and available at www.silkroadstudies.org/ new/docs/CEF/Quarterly/May_2006/Baev.pdf.

18 Al Qalah website, “Map of Future Al-Qaeda Operations”; available at http://www.mailarchive.com/osint@yahoogroups.com/msg04935.html. 
targeting pipeline infrastructure, refineries, and foreign oil workers. Militant groups attacking oil stations in 2006 forced Royal Dutch Shell to shut down four oil facilities in Nigeria. The bomb attack on the pipeline took 106,000 barrels a day-about 10 percent of Shell's total production in Nigeria-off the market, and raised fears that international companies would withdraw from doing business in the country. ${ }^{19}$

Turmoil caused by disputed presidential elections in Nigeria in 2007 left three pipelines blown up, several supply vessels attacked, and many oil workers kidnapped by militant groups. The unstable political and security situation in the Niger Delta forced Chevron to evacuate its personnel, and militants captured some staff members of the Italian oil company Agip. ${ }^{20}$ As a result of the unrest, about 20 percent of the country's export capacities were taken off the energy market.

The most recent incidents that occurred earlier this year involving three U.S. warships and five Iranian fast boats once again demonstrated the fragility and vulnerability of world's energy security. U.S. Navy ships were conducting routine patrols in the Straits of Hormuz when they encountered Iranian boats threatening to inflict damage on them. With about 30 percent of the world's oil supply passing through it, the Straits of Hormuz is one of the world's most critical strategic chokepoints. In 2006, some 17 bbd passed through the straits, supplying the United States, Western Europe, Japan, and other Asian states with oil from Persian Gulf nations, including Saudi Arabia, Iran, and the UAE. ${ }^{21}$

With $3 \mathrm{~km}$-wide inbound and outbound lanes, if the Strait is blocked, only a small amount of oil can be diverted to alternate routes, thus taking millions of barrels per day off the global energy market. According to the International Energy Agency about 17 mbd, or 21 percent of the world's total oil supply, crossed through this route in 2006 . $^{22}$ It is projected that oil flow through the Straits of Hormuz will grow from 17 mbd today to $32 \mathrm{mbd}$ in 2030 - that is, about 28 percent of world's oil and 4 percent of its gas supply could be delivered to consumers in the U.S., Western Europe, and Asia through the strait by 2030. In 2007, about 176 mbd, or 11 percent of Japan's oil imports, came from Iran via the Straits of Hormuz. Oil imports from countries of the Persian Gulf accounted for 90 percent of Japan's total imports in 2006.

China is another major consumer of energy resources from the Persian Gulf, with Iran becoming a major supplier of natural resources for both China and India. In 2005 more than 16 percent of Chinese oil imports came from Iran. This trend is projected to grow dramatically, as China is currently experiencing steady and robust economic growth. Iran's share in China's imports of liquefied natural gas (LNG) is also expected

19 Simon Freeman, “Shell Quits Nigeria Oil Stations as Violence Flares,” TimesOnline (London) (16 January 2006).

20 Jad Mouawad, "Renewed Violence in Nigeria Strains Oil Production,” International Herald Tribune (14 May 2007).

21 Energy Information Administration, “World Oil Transit Chokepoints," available at www.eia.doe.gov/cabs/World_Oil_Transit_Chokepoints/Background.html.

22 International Energy Agency, World Energy Outlook 2005; available at www.iea.org/ textbase/nppdf/free/2005/weo2005.pdf. 
to grow significantly, while the Middle Eastern share of China's overall oil imports is expected to grow from the current 60 percent of total imports to 75 percent by 2015 .

Considering the immense significance of Middle Eastern natural resources for Chinese energy security, and hence for its economic growth, it is likely that in the future China will be competing with the United States over the issue of controlling the Straits of Hormuz. China has been concerned for some time about the strong U.S. presence in the Persian Gulf. Many analysts believe that Beijing's ambitious policy of naval buildup is driven by the need to secure sea routes for energy supplies. Some experts predict that in the future frictions and incidents in the Persian Gulf region involving the U.S. and Chinese navies are unavoidable.

The European Union as the world's largest energy market is heavily dependent on imports of natural resources from politically unstable regions. It has been observing the trends developing in the world's energy security sector with growing concern. Today, the group of nations represented by members of the EU is already the world's largest energy importer. A Green Paper on European Strategy for Sustainable, Competitive, and Secure Energy (2006) was developed in order to take measures to reduce dependence on energy from unstable regions by promoting more transparency, competitiveness, and diversity. It also states that there is an urgent need for investment in order to avoid energy shortfalls caused by ageing infrastructure. ${ }^{23}$ It estimates that a EUR one trillion investment in the energy infrastructure will be necessary over the next twenty years in order to meet projected energy demands.

Already today it is predicted that the EU's dependence on imported oil and gas from unstable regions will rise from the current level of 50 percent of total energy imports to 70 percent over the next twenty to thirty years. In the next twenty-five years, the EU's gas imports, mainly from three countries - the Russian Federation, Norway, and Algeria-will increase from today's level of 35 percent of total energy imports to 80 percent. It is also worth mentioning that fossil fuel sources like oil and gas will account for 90 percent of the world's growing energy demand.

The EU's green paper suggests developing fully competitive internal energy markets which, when created, would ensure the security of energy flows and lower prices. A competitive, transparent, and secure European energy market is being considered as a basic pillar of Europeans' daily lives. ${ }^{24}$ Abandoning protectionism and promoting open markets that guarantee foreign private companies access to the European energy market could improve energy security and promote competitiveness. However, practice does not always conform to theory. In many European countries energy policy still falls under the domain of national security and foreign policy. In other countries, however, oil and gas are seen as purely economic goods, and not strategic ones. Hence, they are left to market regulatory rules. ${ }^{25}$

${ }^{23}$ Commission of the European Community, Green Paper on European Strategy for Sustainable, Competitive and Secure Energy (December 2006); available at http://ec.europa.eu/ energy/green-paper-energy/index_en.htm.

24 Ibid.

25 Frank Umbach, “Europe’s Next Cold War,” Internazionale Politik 62:2 (February 2006). 
The European green paper on energy security pays significant attention to the security of supply, in cases where threats posed by political instability, natural disasters, and terrorist attacks could lead to the collapse of Western economic systems. Increased investments in security measures by private companies, intelligence sharing and analytical assessments, as well as cooperation between governments and industry in information sharing could represent a step forward. The paper also suggests creating a mechanism to provide rapid solidarity and assistance in case one country or a group of countries is affected by energy shortfalls. It also recommends taking steps toward standardizing measures that ensure infrastructure protection. ${ }^{26}$

As part of a coherent external energy policy, the green paper envisions a clear policy on energy diversification and energy security. According to the paper this is to be guaranteed by upgrading existing and building new energy infrastructure, including oil and gas pipelines as well as liquefied natural gas (LNG) terminals. ${ }^{27}$ Independent gas supplies should come from the Caspian Region, the Middle East and North Africa, and cross through Georgia, Ukraine, Romania, and Bulgaria. ${ }^{28}$ The EU demonstrates its readiness to support the private sector in realizing such projects by concrete political, financial, and regulatory measures. The new EU-Africa Strategy that is aimed at interconnecting the energy systems of the two continents was granted priority status, and is seen as a possibility to support Europe's diversification policy. ${ }^{29}$

Dialogue with the major energy suppliers of the EU, such as OPEC, the Gulf Cooperation Council, and Russia (Europe's single largest supplier) is the declared aim of the paper. ${ }^{30}$ The EU seeks to establish a partnership with Russia where both parties are equal, and that is based on predictability and security. Such a partnership could be conducive to long-term broad investments, and hence increase capacities both in upstream and downstream production. The paper once again underlines the need to intensify efforts leading to subsequent ratification of the Energy Charter Treaty (ECT) and the appropriate Transit Protocol by the Russian Federation that guarantees non-discriminatory access for the EU and third countries to the Russian pipeline system.

As described above, growing energy demand and consumption in the world, mainly driven by economic growth and demographic developments in the world's most populous countries such as China and India, along with rising energy prices, political instability in oil and gas rich countries, international terrorism, and attacks on energy infrastructure pose serious threats to the world's energy security. Declines in energy production and stagnation in exploration and extraction sectors and the inability of producers to provide spare capacity further aggravates the already tense situation on the global energy market. High competition between states for securing long-term energy contracts will in the future be the main source of friction, as recent developments in the

\footnotetext{
${ }^{26}$ Commission of the European Communities, Green Paper on European Strategy for Sustainable, Competitive and Secure Energy.

27 Ibid.

28 Ibid

29 Ibid.

30 Ibid.
} 
East China Sea demonstrate. Energy scarcity and decreasing extraction capacities due to a lack of modern technologies in producer countries could further boost energy prices.

The "nervous system" of the global energy distribution network and the oil tankers passing the strategic energy chokepoints such as the Straits of Hormuz, the Straits of Malacca, and Bab el Mandab will continue to remain the main targets of terrorist organizations aiming to destabilize energy markets and thus cause the collapse of the world's economy. Single nation-states, having limited capabilities to prevent such attacks, will not be able to cope with these tasks alone. Joint efforts and an institutionalized approach are needed to address the challenges threatening energy security in the twenty-first century. In today's world, where energy markets have ceased to be regional, and are now global in nature, security does not mean providing protection to a certain single energy infrastructure anymore. Energy security has become an issue of common responsibility and concern. Not only does the physical security of infrastructure need to be guaranteed; the strengthening of institutional capacities could also play a vital role. Promoting energy efficiency, pursuing diversification policies, and creating a favorable investment climate in the countries producing energy would all be steps toward providing more security. Market liberalization, transparency, competitiveness, and ensuring foreign private energy companies access to domestic energy markets would bring benefits to consumers and producers equally.

\section{NATO and Energy Security}

As seen above, energy security has become an issue of immense importance to the United States and its European allies. Although there is a general perception in many European countries that market regulatory rules alone would be sufficient to ensure the security of energy supplies, concerns about energy insecurity have prompted NATO to discuss the issue within the Alliance. Energy security is not a new concern for NATO and its member states. Since NATO's inception, ensuring the uninterrupted flow of energy resources has been a priority for the Alliance, as it has always been directly linked to the organization's operability and the security of its member states. For the Alliance, energy security has always meant first and foremost ensuring a steady supply of fuel to its military forces. Separate and distinct military storage and distribution systems were set up, and are an integral part of the NATO pipeline system.

The Alliance has regularly dealt with this issue in different fora and formats. NATO’s Strategic Concept from 1991, and then later the Strategic Concept from 1999 identify the disruption of flows of vital resources as a security challenge and risk to the Alliance: “Alliance security interests can be affected by other risks of a wider nature, including acts of terrorism, sabotage and organized crime, and by the disruption of the flow of vital resources."

31 NATO’s Strategic Concept, adopted on 23-24 April 1999; available at www.nato.int/ docu/pr/1999/p99-065e.htm. 
There are also references to energy supplies in the Comprehensive Political Guidance that provides the framework and political direction for NATO's continuing transformation over the next ten to fifteen years. Aside from these official mentions, discussion on this topic takes place within the Alliance, and NATO member states support workshops and forums addressing this issue. Several workshops held in several capitals such as London, Prague, and others discussed potential threats to energy infrastructure and the free flow of energy. Additionally, NATO ships regularly conduct preparatory route surveys at chokepoints throughout the Mediterranean. Scientists from NATO and partner countries work together to address issues relating to energy security and identify possible roles for the Alliance. NATO also maintains close relationships with private energy companies, such as Royal Dutch Shell, BP, E.On, and Ruhrgas.

Though energy issues had been discussed in different formats, before NATO's Riga Summit, energy and energy security were never a consistent part of NATO's policy statements, and the Alliance had never before developed a systematic approach to these issues. In the Riga Summit declaration, NATO for the first time in its history put energy security on its political agenda, and paved the way for internal debates in order to determine what NATO's role should be and where it can add value to the world's overall energy security:

As underscored in NATO's Strategic Concept, Alliance security interests can also be affected by the disruption of the flow of vital resources. We support a coordinated, international effort to assess risks to energy infrastructures and to promote energy infrastructure security. With this in mind, we direct the Council in Permanent Session to consult on the most immediate risks in the field of energy security, in order to define those areas where NATO may add value to safeguard the security interests of the Allies and, upon request, assist national and international efforts. ${ }^{32}$

The Riga Summit Communiqué once again underscored the Alliance’s increasing interest in securing energy flows and protecting energy infrastructure. International terrorism—primarily through threats posed by terrorist attacks on oil tankers, prime shipping lanes, and strategic chokepoints-as well as instability in the Middle East region and natural disasters highlight the need for a systematic approach to the issue.

Though there is no direct mandate for NATO to deal with energy security issues, in the contemporary debates in the capitals of member states many experts and government representatives are focusing on the task of setting up a system of collective energy security and energy solidarity. In 2006 the Polish government developed an idea of creating an "Energy NATO," under the rubric of which the European Union and NATO states would provide mutual support in energy matters, in any form, but without the use of force. Though some EU governments believe that NATO's attempts to play a role in energy security could be premature at this stage, it is commonly accepted that there certainly are some fields where NATO could add value to overall energy security. There should be a multifaceted approach to the question of NATO's potential role

32 North Atlantic Treaty Organization, "Riga Summit Declaration,” Riga, Latvia, 9 November 2006; available at www.nato.int/docu/pr/2006/p06-150e.htm. 
in energy security. It could range from initiating political dialogue with all partners and stakeholders involved, monitoring and assessment of energy security and threats, to intelligence sharing and direct involvement in protecting critical energy infrastructure.

Since NATO has already developed formats such as the Istanbul Cooperation Initiative (ICI) and the Mediterranean Dialogue, where it already closely cooperates with partner countries, including the world's leading oil suppliers, using these frameworks for consultation on energy issues would make an important contribution to contemporary debates related to energy security. Conducting joint exercises, civil emergency rescue missions, and providing training to the representatives of these countries would be an additional step in this direction. However, many experts believe that NATO's involvement in energy security issues could be misinterpreted in some countries as NATO forging an energy alliance against them. Opponents of the Alliance's involvement in energy issues believe that the liberalization of European energy markets, further integration of national energy grids, and the diversification policies of European nations lie beyond the organization's aims and mandate. They also believe that the "militarization" of issues that are of a completely economic nature will have negative effects, and could create tensions with producer countries, especially Russia.

In order to define the areas where NATO could add value, we have to identify fields of critical importance for NATO and its member states. Another aspect would be to determine whether NATO has the capabilities to address threats that have already been identified, and whether consensus could be reached on the Alliance's involvement in protecting energy infrastructure and ensuring energy security. It is commonly recognized that securing its own domestic energy needs is each nation's responsibility; however, a political assessment has to be done to identify to what extent the energy vulnerability of a particular Allied nation could be translated into a broader concern for the Alliance as a whole. Dr. Cezary Lusinski, Director of the Department of International Security Policy in the Polish Defense Ministry, suggests providing Allied solidarity in case one member state were exposed to energy imbalances and vulnerabilities. In his words, "nurturing solidarity would be the best response to the endangerment of interests of an Allied nation. We can see the value of such solidarity in response to nonconventional threats in such examples as the recent cyber-attack on Estonia."33

Andrew Monaghan, from the Research Department of the NATO Defense College, in a speech on 20 July 2007 at the NATO School in Oberammergau, outlined the benefits of NATO's involvement in energy security. First, it explicitly involves the U.S. and Turkey, which are Europe's major energy partners. Turkey's involvement provides additional value, as the country is setting itself up as the "fourth major energy artery to

33 Dr. Cezary Lusinski, Director, Department of International Security Policy, Polish Ministry of Defense, “Energy Security: Any Role for NATO?” in Energy Security and Security Policy: NATO and the Role of International Security Actors in Achieving Energy Security, ed. Phillip Cornell (Oberammergau: NATO School, November 2007). 
Europe.”34 Second, uninterrupted energy flows are directly linked to the Alliance's capabilities to carry out its missions and operations. The success of NATO's military operations are very much dependent on large quantities of secure fuel. ${ }^{35}$ Having different partnership formats with many countries, NATO is the best avenue to discuss issues related to energy security and the security of energy infrastructure. NATO conducts dialogue with Russia within the framework of the NATO-Russia Council; within the framework of the Individual Partnership Action Plan (IPAP), the Alliance maintains partnerships with relevant energy producers and transit countries. Central Asian and Persian Gulf countries also have dialogue with NATO in different formats and enjoy specific partnerships with the Alliance.

Given NATO's direct interest in ensuring a secure flow of energy resources and in minimizing the threats posed to its member states, a threat-based approach to the issue has been developed by NATO experts, and some "niche areas" have been identified where NATO can add value to international efforts to improve energy security. Monitoring and assessing the energy security situation is the field where, according to Jamie Shea, Director of Policy Planning at NATO, the Alliance can play the most meaningful role. He suggests setting up a permanent monitoring and assessment mechanisms to closely monitor developments related to energy security. Such cooperation should be implemented in close consultation with NATO members and partner countries. Joint international military staffs should prepare analysis and intelligence reports that would be provided to the North Atlantic Council (NAC) for further decisions and actions. Cooperation with other international institutions such as the European Union and the International Energy Agency and the involvement of major oil companies will certainly play an important role as well. ${ }^{36}$ NATO and the EU are already involved in close cooperation in the Science and Technology (S\&T) programs for energy infrastructure security. Discussions and activities within these programs directly address the issues related to energy and infrastructure security.

Jamie Shea also recommends that the North Atlantic Council (NAC) establish an Energy Security and Intelligence Analysis Cell. A similar cell already exists that deals with issues related to international terrorism. Intelligence could be gathered by member states and partner countries, and a mechanism for intelligence sharing on energy security could be developed in close consultation with all parties involved. NATO could play a significant role in assessing threats posed to key elements of the global energy infrastructure based on the intelligence provided by the partner countries.

34 Andrew Monaghan, Research Department, NATO Defense College, "The Euro-Atlantic Area, Russia and Energy Interdependence,” paper presented at the NATO School in Oberammergau, Germany, on 20 July 2007. Published in Energy Security and Security Policy: NATO and the Role of International Security Actors in Achieving Energy Security, ed. Phillip Cornell (Oberammergau: NATO School, November 2007).

Ibid.

36 Jamie Shea, “Energy Security: NATO’s Potential Role,” NATO Review (Autumn 2006); available at www.nato.int/docu/review/2006/issue3/english/special1.html. 
NATO could also add value to the monitoring of important maritime shipping lanes and the world's strategic energy chokepoints. These are areas of significant importance not only to NATO and its member states, but to partner countries as well. NATO's capabilities in monitoring and assessing the threats - threats that are often too large or diffuse for individual states to cope with on their own-would be very important for ensuring the secure transfer of vital resources through the places that are vulnerable to disruption and attack by terrorists.

Africa is the region where both organizations-NATO and the European Unioncould most productively combine their efforts. For the last couple of years Africa has become a high priority issue for Europe. The development of an EU-Africa Partnership on Infrastructure and plans to develop an Africa-Europe Energy Partnership underline the importance of the region to the EU. On the other hand, NATO is also very much interested in developing close partnerships in Africa. For example, NATO has provided support to African Union (AU) operations in Darfur. Given Africa's rich energy resources and the threats posed to the energy infrastructure there, it should be in the interests of NATO and the EU to bolster cooperation in the region on issues related to energy security.

Many Allied nations are very much involved in developing policies for protecting what they call critical energy infrastructure. This is of the utmost importance, since terrorist attacks and damage to the energy infrastructure would have severe negative effects, not only for the world's energy market but for each individual national economy as well. In various cases, Allied nations cooperate with producer and transit countries bilaterally, offering recommendations and training for security personnel assigned to energy infrastructure. Joint groups of experts conduct surveys and assessments of energy facilities and infrastructure and compile reports identifying gaps and the most vulnerable sectors of the energy infrastructure. Some Allied nations have a very positive track record in this field, and if their efforts were combined under a NATO umbrella, other small member states could benefit from it.

NATO could use its maritime surveillance capabilities for patrolling and, in cases of necessity, defending energy infrastructure critical to the organization and its member states. As an immediate response to the terrorist attacks against the United States on 11 September 2001, NATO started Operation Active Endeavor, in which NATO ships patrol the Mediterranean, monitoring shipping and providing escorts to non-military vessels through the Straits of Gibraltar to help detect, deter, and protect against terrorist activity. The same model could be applied to the missions aimed at protecting energy infrastructure and oil tankers passing through maritime shipping lanes. Such missions could also have a deterrent effect, sending clear signals to terrorists that the Alliance is willing to ensure an uninterrupted flow of natural resources to its member states. By patrolling the main energy chokepoints, NATO ships could also assist private oil companies in providing threat assessments and information about threats to the energy infrastructure. Providing training and support to security services in producer and transit countries is another field where NATO could enhance overall energy security. 
Many experts believe that NATO could also provide direct security assistance to a single nation or group of nations experiencing difficulties in protecting their energy infrastructure and ensuring a free flow of energy. In such cases, NATO could even conduct interdiction military operations aimed at securing vulnerable energy infrastructure during a time of need. It could include assistance to maritime services and aerial patrolling and assistance in intelligence sharing. NATO could also help nations to develop emergency plans and (in the most extreme cases) deploy Rapid Reaction Forces to protect energy assets.

\section{Conclusion}

Though energy security and protecting energy infrastructure have always been on NATO's political and military radar, NATO still has to define what the Alliance's role in ensuring better energy security will be. Increasing demand for energy resources and tense energy markets, coupled with threats posed to energy infrastructure by terrorist attacks and natural disasters could lead to an energy crisis in which the free flow of energy resources will be interrupted. Recognizing those risks, NATO has been regularly addressing these issues in a variety of different venues. There are certainly areas where NATO can add value to overall energy security—for example, by providing assistance to its member states and partner nations in threat assessment, monitoring and assessing the energy security situation, providing assistance and training to domestic security services, and intelligence sharing with partner countries and private oil companies. There is a need for further discussions and dialogue within the Alliance and with partner nations to define what could be the best contribution a military-political alliance such as NATO can provide. 


\section{Bibliography}

Baev, Pavel K.. "Reevaluating the Risks of Terrorist Attacks Against Energy Infrastructure in Eurasia." China and Eurasia Forum Quarterly 4, no. 2 (2006).

Frank, Umbach. "Europe's Next Cold War." Internazionale Politik 62 (2006).

Harks, Enno. "The Conundrum of Energy Security: Gas in Eastern and Western Europe." The International Spectator 41, no. 3 (2006).

Jad, Mouawad. "Renewed Violence in Nigeria Strains Oil Production." International Herald Tribune (2007).

Jamie, Shea. "Energy Security: NATO’s Potential Role." NATO Review (2006).

Socor, Vladimir. "Gas Supplier's Cartel: Not an 'OPEC,' but a Cartel all the Same ." Eurasia Daily Monitor 4, no. 62 (2007).

Susanne, Peters. "The Future Energy Security Environment: No Alternative to a Radical Shift." In Energy Security and Security Policy: NATO and the Role of International Security Actors . Kent State University, Geneva, 2004. 